\title{
Eliza Grzelak, $O$ „prawdach” w czasach postprawdy. Perspektywa komunikologiczna, Wydawnictwo Rys, Poznań 2019, ss. 325
}

Dr hab. Eliza Grzelakowa, zatrudniona na stanowisku profesora nadzwyczajnego w Collegium Europaeum Gnesnense (Instytut Kultury Europejskiej) Uniwersytetu im. Adama Mickiewicza, tak sama charakteryzuje swoje opracowanie: „Punkt wyjścia do analizy zebranego materiału [zob. niżej - B.W.] stanowiło podstawowe pytanie o zasadność wprowadzenia nowej kategorii - postprawdy obok już istniejących - kłamstwa i prawdy. Czy faktycznie jest to konieczne z perspektywy opisu współczesnego systemu aksjologicznego? Czy ustanowienie tej kategorii nie stanowi usprawiedliwienia procesu dewaluacji prawdy?" (s. 23). Wcześniej jeszcze autorka stwierdza: „Pojawiają się jednak pytania: skoro kłamstwo jest wszechobecne, jest jednym z podstawowych narzędzi komunikacji, dlaczego właśnie teraz tak dużą uwagę zwrócono na podrzędną rolę prawdy, co spowodowało, że pojawiła się konieczność stworzenia nowego bytu - postprawdy?” (s. 12). „Czym obecna rezygnacja z prawdy różni się od dotychczasowej? Czy postprawda jest odmianą prawdy, czy też nową wersją kłamstwa?” (s. 20). „By móc zweryfikować sformułowane wyżej wątpliwości, należało wcześniej znaleźć odpowiedzi na inne pytania. Pierwsze z nich dotyczyło samej prawdy. Nie było moim celem sformułowanie jej kolejnej definicji, raczej spojrzenie na nią z perspektywy komunikologii. Dotychczas [...] rozpatrywano prawdę jako przekaz jednostronny oceniany aksjologicznie, weryfikowano jego zgodność z myślą, przekonaniem nadawcy. Odmiennie klasyfikowano kłamstwo, w tej relacji współuczestniczyli nadawca i odbiorca. Czy jednak w związku z faktem, że mówiąc o prawdzie, najczęściej mamy do czynienia $\mathrm{z}$ opisem prawdy, nie powinniśmy również uwzględniać odbiorcy w procesie werbalnej kreacji prawdy? [...] Interesowało mnie, w jakim stopniu odbiorca celowy poprzez swe kompetencje oraz oczekiwania wpływa na nadawcę i jego 
sposób kreacji rzeczywistości, czyli na prawdziwość przekazu oraz w jakim stopniu otwarta formuła przekazu umożliwia odbiorcy interpretację przekazu zgodną z własnymi oczekiwaniami? [...] Szukając odpowiedzi na sformułowane powyżej problemy podstawowe [...], pytałam [jak - o tym niżej - B.W.] o:

- relacje między prawdą a prawdomównością,

- stopień weryfikowalności przekazu w ramach kategorii prawda/fałsz, czyli granicę między prawdą a fałszem,

- granice usprawiedliwionego kłamstwa,

- słuszność rezygnacji z konwencji na rzecz prawdy,

- skuteczność ironii jako narzędzia kreacji prawdy, szczególnie w komunikacji elektronicznej,

- wykorzystanie przekazu naukowego jako źródła prawdy w reklamie,

- stopień emocjonalności i merytoryczności debaty na portalach społecznościowych,

- wykorzystanie prawdy w debacie politycznej i akceptacji kłamstwa w tej formie komunikacji [autorka świadomie ograniczyła się do przekazu stricte politycznego (parlamentarnego), rezygnując (s. 21), z dobrym (moim zdaniem) uzasadnieniem z przekazu dziennikarskiego: „Zrezygnowałam z analizy bardzo ważnego przekazu dziennikarskiego, który obok politycznego jest uznawany za podstawowy nośnik postprawdy. Jednak skomplikowana i dynamicznie zmieniająca się sytuacja w polskiej przestrzeni medialnej wymaga odrębnego, bardzo złożonego i obszernego opisu. Konieczne jest między innymi zredefiniowanie terminu «dziennikarz», wskazanie zakresu działalności dziennikarskiej, publicystycznej w przestrzeni wirtualnej, dokonanie oceny aktualnej sytuacji prawnej dziennikarstwa" - B.W.],

- prawdę, kłamstwo, postprawdę jako narzędzia polaryzacji społecznej,

- naukę, wiedzę jako źródło obiektywnej prawdy.

Ta wielość szczegółowych zagadnień w istocie dotyczyła dwóch podstawowych problemów:

- granic prawdy, kłamstwa i postprawdy oraz aktualności ich definicji w kontekście wybranych zachowań komunikacyjnych,

- zasadności powszechnych obaw o dewaluację prawdy i źródła oraz przyczyny tego procesu" (s. 24).

Zgromadziwszy bardzo obszerny materiał językowy (o czym niżej) i uzbrojona w polimetodologiczne instrumentarium badawcze (o którym też niżej), osiągnęła autorka zamierzony cel badawczy (sama pisze o nim następująco: „Zakres dotychczas prowadzonych przeze mnie badań oraz teoria, że portale społecznościowe wspomagają postprawdę, sprawiły, że skoncentrowałam 
uwagę na tej formie komunikacji, jednak uzupełniłam ją, zgodnie z tezą o wzajemnym przenikaniu się obu przestrzeni, przekazami uruchamianymi w świecie realnym" (s. 20-21)). Powstała praca wybitna, o której wartości stanowią w moim przekonaniu przede wszystkim następujące aspekty:

1. Aktualność. „Poniższa publikacja jest wynikiem prowadzonych od kilku lat badań nad komunikacją interpersonalną w Polsce, determinizmem technologicznym tej komunikacji oraz modyfikacją systemu aksjologicznego w świecie wirtualnym” (s. 11). „Badania prowadziłam od 2009 roku do 2018 roku, w tym czasie publikowałam cząstkowe wyniki [niektóre partie monografii oparte są na opublikowanych wcześniej rozprawach i artykułach, przy czym zawsze autorka przeredagowuje tekst wcześniejszy, uzupełnia i aktualizuje dane głównie na podstawie stosownych wywiadów i ankiet, o których dokładnie informuje - B.W.], dotyczące wielu zagadnień powiązanych z kreacją prawdy [...]. Skoncentrowałam swoją uwagę na portalu społecznościowym Facebook. Tematy najczęściej na nim poruszane pozwoliły na wybór także innych portali do obserwacji, były to fora dyskusyjne [...] Gazeta Wyborcza, Polityka, na temat.pl, Niezależna.pl, Ośrodek Monitorowania Zachowań Rasistowskich i Ksenofobicznych, o2.pl, kafeteria.pl, caferoyal.pl, dziennik.pl, oko.press.pl, natemat.pl. Ze względu na zakres badań najistotniejsze były nieoficjalne komentarze, które poszerzały krąg kreatorów prawdy. Mając na uwadze wszystkich uczestników debaty, nadawców, odbiorców i obserwatorów, rozszerzyłam przedmiot badań o wypowiedzi formułujące oczekiwania wobec przekazu, opisujące jego częściową interpretację, zwerbalizowane w ankietach i wywiadach; badaniami ankietowymi objęłam w latach 2009-2018 ponad 1500 osób, respondenci reprezentowali różne grupy wiekowe i zróżnicowaną przynależność wspólnotową" (s. 22-23).

Aktualność stanowi wielką zaletę opracowania. Autorka zdążyła uwzględnić w swoich uwagach i spostrzeżeniach zalety i wady reformy Jarosława Gowina, a nawet (choć to już 2019 rok) zabójstwo prezydenta Gdańska Pawła Adamowicza, które dało Elizie Grzelakowej asumpt do następującego stwierdzenia: „Zabójstwo prezydenta Gdańska potwierdziło, że od złej, pełnej nienawiści mowy do złych, nienawistnych czynów droga jest bardzo krótka" (s. 298).

2. Podstawa źródłowo-materiałowa. Autorka pisze: „Podstawę materiałową badań stanowiły [...] przekazy elektroniczne, mowy parlamentarne, teksty reklam, wypowiedzi lekarzy, ironiczne kreacje prawdy. Istotna jednak ze względu na omawiany problem, czyli redakcję przekazu zgodną z oczekiwaniami odbiorców, była analiza interpretacji wskazanych komunikatów i ich ocena etyczna formułowana przez odbiorców" (s. 21).

Podstawa źródłowo-materiałowa monografii jest wyjątkowo solidna i obszerna. Sam spis źródeł (literatura podmiotowa) zajmuje aż 7 stron 
(319-325). Taka rzetelna podstawa umożliwia wiarygodne wnioski i w ogóle gwarantuje ważne wyniki naukowe. Charakteryzuje też dobrze warsztat naukowy autorki i pozwala na przypuszczenie (niezależnie od deklaracji expressis verbis), że jest ona zdania (wspólnego ze zdaniem recenzenta), iż językoznawstwo jest nauką empiryczną.

3. Komunikologiczne instrumentarium badawcze, o którym autorka pisze: „[...] uwzględniłam kilka metod, charakterystycznych dla badań komunikologicznych: ankietę, wywiad, analizę tekstów oraz obserwację uczestniczącą. Ankietę i wywiad wykorzystałam, by ustalić oczekiwania odbiorców przekazu, ich ocenę aksjologiczną komunikatu w zakresie prawda/fałsz oraz by zweryfikować zasady wyboru treści. Ustalałam, które fragmenty przekazu elektronicznego czytane są najczęściej. W ankietach pytałam także o rozumienie kłamstwa [...]. Ankieta była badaniem ogólnym, choć dominowały pytania otwarte. [...]. Bardziej szczegółowe były wywiady, które prowadziłam w formie swobodnej rozmowy $[. .$.$] . Za pomocą zróżnicowanych tematycznie ankiet przebadano$ ponad 1500 osób [...]. Wywiady przeprowadziłam z około 500 osobami, trwały one ponad godzinę i nie były nagrywane, post factum sporządzałam notatki lub sporadycznie, za zgodą respondenta, notowałam pojedyncze spostrzeżenia. Analiza tekstu, czyli opis i interpretacja najbardziej charakterystycznych cech komunikatu, w tym przypadku objęła klika zagadnień: neosemantyzację pojęć, będących nazwami wartości, interpretację przekazu w ramach kategorii prawda/ fałsz [...]. Najistotniejsze było sprawdzenie, w jaki sposób w różnych sytuacjach tworzy się przekaz, odpowiadający aktualnym potrzebom odbiorcy, z tego też powodu uznawany przez niego za prawdziwy. Wybrałam teksty formułowane w ramach dopuszczalności kłamstwa (białe kłamstwo) oraz teksty kreujące prawdę poprzez kłamstwo (ironia). Pod uwagę wzięłam także reklamę, która z natury uznawana jest za przekaz kłamliwy. W tym ostatnim przypadku najpierw zweryfikowałam za pomocą ankiet i wywiadów ocenę metod oddziaływania nadawców, następnie [...] wybrałam do analizy i opisu teksty marketingowe, w których najczęściej sięga się po argumenty „naukowe” i argument autorytetu, czyli te, które respondenci uznali za najbardziej godne zaufania. [...] Zwróciłam także uwagę na dyskurs parlamentarny, jako najbardziej zneutralizowany i poprzez swoje utrwalenie kontrolowany przekaz polityczny [...]" (s. 25-26).

Przekonująco autorka uzasadniła koncentrację uwagi na dwóch dyskursach: antyszczepionkowym i antyimigranckim (s. 31).

4. Imponujące zaplecze erudycyjne pracy. Multidyscyplinarny wykaz bibliograficzny (Monografie i artykuły. Omówienia publicystyczne), w którym nie dostrzegam żadnych istotnych luk, obejmuje aż 180 pozycji, z czego znacznie więcej niż połowę stanowią książki, nieraz wielotomowe. Osobno 
zestawiła autorka 13 wyzyskanych słowników i encyklopedii - tu już wyłącznie książek. Skoro już się tutaj podkreśla bogactwo literatury przedmiotu, godzi się zauważyć, że bardzo wysoki jej odsetek stanowią pozycje obco-, głównie anglojęzyczne. Nie brak także pozycji w języku polskim, ale autorstwa wybitnych uczonych zagranicznych, takich jak René Descartes, Umberto Eco, Erich Fromm, Hans Georg Gadamer, Paul Grice, Martin Heidegger czy Ludwig Wittgenstein. Ogląd zestawienia bibliograficznego autorstwa dr hab. Elizy Grzelakowej uświadamia nam, jak wiele klasycznych pozycji językoznawstwa, filozofii, semantyki itp. rangi światowej mamy już przełożonych na język polski.

5. Wnikliwość, dociekliwość, wszechstronność, kompetencja i precyzja prezentowanych w pracy analiz i interpretacji. Szczególną uwagę zwróciłbym tutaj na opis determinizmu technologicznego relacji interpersonalnych. W części za Radosławem Mysiorem opisała autorka dwa bardzo ważne dla tego determinizmu pojęcia e-autochtonów i e-imigrantów: ,[...] e-autochtoni to osoby, które urodziły się lub wychowały w świecie postmediów, którym w procesie uspołecznienia towarzyszyły elektroniczne narzędzia komunikacji od komputera po smartfony i inne tzw. inteligentne rozwiązania. Sa to osoby, których relacje bezpośrednie warunkowane są sprawnością w zakresie obsługi nowych mediów. [...]. Ich pierwszym miejscem jest e-przestrzeń, tam mają przyjaciół/znajomych, opowiadają im o sobie i dzielą się poglądami. Jest to świat, w którym zachowują się odważniej, chętniej zabierają głos. [...]. Z upływem czasu do tego świata wkroczyli e-imigranci, zaczęli w nim funkcjonować zgodnie z zastanymi zasadami, czyli pod dyktando młodych. Nie są tak sprawni technologicznie, uczą się poprzez naśladownictwo, ich przewodnikami są cyfrowi tubylcy. W ten sposób w świecie wirtualnym nastąpiło odwrócenie ról, mistrzami dla starców stali się młodzi, odwrotnie niż jeszcze do niedawna było w świecie realnym” (s. 13-14). „Badając, w jakim stopniu e-determinizm rzutuje na procesy komunikacyjne, jak modyfikuje kody wspólnotowe, wpływa na relacje na granicy kultur, zmienia strukturę społeczną, dostrzegłam, że wraz z modyfikacją kodu wspólnotowego postępuje modyfikacja systemu aksjologicznego, będącego jego fundamentem i identyfikatorem" (s. 17).

Praca Elizy Grzelakowej obfituje w trafne konstatacje szczegółowe, np. na s. 134: „Badania ankietowe wykazały, że tylko 32\% pytanych uważa, że w niektórych reklamach można odnaleźć prawdziwe informacje, nikt nie przyznał, że istnieją reklamy będące przekazem całkowicie prawdziwym". Dość często takie konstatacje poparte są jednym tylko argumentem - ale za to mocnym, jak na s. 20: „W polskiej debacie publicznej epitet «kłamca» przestał budzić sprzeciw, jest lekceważony". Konstatacja ta uzasadniona jest tylko jednym argumentem w przypisie 34: ,W 2018 roku przydomkiem premiera Polski stało 
się określenie «Mateuszek kłamczuszek»; rząd i premier nie uznali tego epitetu za naruszający ich dobra osobiste i nie wytoczyli z tego powodu procesu".

6. Jako skutek wyliczonych wyżej walorów - ważne i dobrze udokumentowane wyniki naukowe. Jest ich wiele - zarówno ogólnych, jak i szczegółowych, i wolno sądzić, że różne wyniki szczególnie zainteresują różnych czytelników książki Elizy Grzelakowej (a myślę, że oprócz językoznawców będą wśród nich także przynajmniej medioznawcy i kulturoznawcy).

7. I na koniec - umiejętności pisarskie Elizy Grzelakowej, która jest świetną stylistką i pisze jasno, klarownie, atrakcyjnie i - w miarę możliwości - (a materia opracowania jest bardzo trudna) przystępnie.

Poprawy (a raczej uściślenia) wymagają tylko dwie kwestie. Na s. 40 autorka pisze: „Słowo «prawda» pojawiło się w języku polskim w XIV wieku [...]". Tymczasem w XIV wieku słowo prawda zostało udokumentowane filologicznie - natomiast jako element prasłowiańskiego dziedzictwa leksykalnego występowało w języku polskim od zawsze. Niezbyt ścisłe stwierdzenie znajdujemy na s. 44 i 260 (gdzie mowa o tym, że łacińskie veritas i greckie (homeryckie) alethei dają początek polskiemu słowu prawda). Greckie alethei wpłynęło tylko na znaczenie łacińskiego veritas i polskiego prawda w pewnych kontekstach. Jednym słowem, trzeba tu precyzyjnie odróżnić pochodność etymologiczno-słowotwórczą od wpływu na semantykę (co też jest zagadnieniem etymologicznym, chociaż z innego poziomu - nie etymologiczno-słowotwórczego).

Oczywiście te niejasności (niezręczności) sformułowania nie rzutują w najmniejszym nawet stopniu na bardzo wysoką ocenę recenzowanej monografii. Dla porządku stwierdzę expressis verbis: monografia dr hab. Elizy Grzelakowej $O$,prawdach” w czasach postprawdy. Perspektywa komunikologiczna jest dziełem wybitnym (poleciłbym ją nie tylko językoznawcom, ale w ogóle humanistom), doskonałym i w zamierzonym zakresie wyczerpującym. Jestem głęboko przekonany o tym, że oto doczekaliśmy się opracowania tytułowego problemu na miarę naszych czasów. Dzięki tematowi i szerokiej podstawie empirycznej (źródłowo-materiałowej) monografia Elizy Grzelak ma szansę wejść do kanonu klasycznych pozycji współczesnej humanistyki. 